\title{
Cameroon publications in the Science Citation Index Expanded: Bibliometric analysis
}

\author{
Donald Raoul Tchuifon Tchuifon ${ }^{1}$, Hui-Zhen $\mathrm{Fu}^{2}$ \& Yuh-Shan $\mathrm{Ho}^{3 *}$ \\ 1. Department of Chemistry, Faculty of Science, The University of Dschang, LANOCHEE Laboratory, BP. Box 67 \\ Dschang, Cameroon; tchuifondonald@yahoo.fr \\ 2. Department of Information Resources Management, School of Public Affairs, Zhejiang University, Hangzhou 310058, \\ People’s Republic of China; huizhen.927@163.com \\ 3. Trend Research Centre, Asia University, Taichung 41354, Taiwan; ysho@asia.edu.tw \\ * Correspondence
}

\author{
Received 23-XI-2016. Corrected 29-VI-2017. Accepted 28-VII-2017.
}

\begin{abstract}
Cameroon is one of the six countries of Central Africa with more than 20000000 residents. To characterize the Cameroon research performance, Cameroonians publications in the Science Citation Index Expanded during the period of 1936-2015, indexed in the Thomson Reuters SCI-EXPANDED database, were studied in this work. All documents of that period with Cameroon in the address field were included in the study. The document type, language, trend and collaborations were analyzed, as well as the output of different subject categories. Performances of countries, institutions and authors, including total, single, collaborative, first author, and corresponding author publications were also analyzed. Articles were analyzed by the scientific output and research performances of individuals, institutions and collaborative countries with Cameroon. Analyses included 8457 articles ( $85 \%$ of 10591 Cameroonian publications). These bibliometric analyses of Cameroonian publications provided interesting insights concerning authors, institutions and collaboration patterns. Results showed that research in Cameroon was highly dependent on foreign collaborations, and the international collaboration was responsible for the increasing number of publications over the years. It was found that the articles with either first authors or corresponding authors from outside Cameroon got more citations than the others, and that the articles without any international collaboration had lower citations. The number of articles indexed by SCIEXPANDED has seen an increase in terms of Cameroonian articles that is considerably greater that the increase in number of all articles in SCI-EXPANDED. Articles were more frequent than other types of publication and they were mostly in English. The University of Yaoundé I ranked top one in inter-institutionally collaborative articles, the rank of the total inter-institutionally collaborative articles, and the rank of first author articles and corresponding author articles. The University of Yaoundé I also was in an absolute leading position from 1970s to 2015 , followed far away by the other institutions. The categories of tropical medicine, plant sciences, environmental and occupational public health, and infectious diseases, represented the largest number of published articles. Even though physics and chemistry dominated the ranking of the top 20 best Cameroonian authors, an independent mathematics article was the most cited, with 60 citations in 2015 to a Cameroonian author. The top three productive researchers were T. C. Kofane, B. T. Ngadjui, P. Woafo, all from University of Yaoundé I. France and the USA dominated the ranking of countries with strong scientific collaboration with Cameroon. Rev. Biol. Trop. 65 (4): 1582-1591. Epub 2017 December 01.
\end{abstract}

Key words: Africa, Web of Science, bibliometric analysis, Cameroon, Science Citation Index Expanded.

Cameroon is one of the six countries of Central Africa, and it has a total surface area of $475650 \mathrm{~km}^{2}, 466050 \mathrm{~km}^{2}$ of land and 9600 $\mathrm{km}^{2}$ of sea with more than 20000000 residents (National Institute of Statistics, 2010). The first Cameroonian university was created in 1962 , two years after the independence of Cameroon and one year after the proclamation of the Federal Republic of Cameroon. This first Federal University of Cameroon, based in Yaoundé, had only about 300 students (Ndjodo \& Onana, 2012). In 1977, nearly 10000 students were 
enrolled. The need for decentralization of the university system in 1978 led to the opening of the first two academic centers, Douala and Dschang. Two other centers were added later: Ngaoundéré in 1982, and Buea in 1985 (Ndjodo \& Onana, 2012). In 1992, on the eve of the university reform, the university system hosted more than 37000 students. Despite the existence of provincial centers, the centralizing character around the University of Yaoundé, however, remained very strong, since the other four centers remained under-equipped.

In January 1993, a thorough reform of Higher Education took place and decree $\mathrm{n}^{\circ}$ 92/74 of 13 April 1992 transformed the university centers into state fall Universities (Biya, 1992; 1993). At the same time, a second university called Yaoundé II, Soa was created in the outskirts of Yaoundé. According to its legal and economic vocation, it hosted about 10000 students in 1993 (Biya, 1993). The former lone university then became University of Yaoundé I, and hosted more than 25000 students. Thus Cameroon became a state with six state universities instead of one. The balancing of these universities to provincial universities followed in subsequent years, and the capital did not welcome more students than it did in 1992. These six institutions operated the university system from 1993 . Very recently, two other universities were created in the country, namely, the University Maroua (decree $n^{\circ}$ 2008/280 of 09 August 2008) and the University of Bamenda (decree $n^{\circ}$ 2010/371 of 14 December 2010). During that time, many independent research and national institutes were created.

In order to present the research situation in Cameroon, we used a bibliometric analysis. Bibliometric methods as a common research tool have been widely used to measure the scientific performance of countries (Glänzel, 2000; Guan \& Gao, 2008), measuring aspects usually covering research specialties with journals (Yamazaki, 1994; Schubert, Glänzel \& Braun, 1989), subject categories (Pouris, 1989; Moed, de Bruin, \& Van Leeuwen, 1995), collaborative countries and institutions (Glänzel,
1996, 2000; de Haan, 1997). Bibliometric analysis is a useful method for characterizing scientific research (Moravcsik, 1985; Fu \& Ho, 2013; Ivanović, Fu \& Ho, 2015) which can be used to make decisions regarding the development of science (Lucio-Arias \& Leydesdorff, 2009). Furthermore, research trends in certain scientific fields or the research focuses, journals, scientific conferences, scientific institutions and countries within the world science community can be determined based on bibliometric indicators (Wang, Yu, \& Ho, 2010). Moreover, most cited papers with a significant influence in related fields have been investigated in recent bibliometric literatures (Hannerz, 2010; Ponce \& Lozano, 2010, Shadgan, Roig, Hajghanbari, \& Reid, 2010); and a bibliometric analysis can help to classify/suggest new research institutes in the country. Besides, analyses of the scientific research production of countries belonging to all continents have been studied using bibliometric indicators, such as those from Serbia (Ivanović \& Ho, 2015), Russia (Markusova, Jansz, Libkind, Libkind, \& Varshavsky, 2009), Netherlands (Moed et al., 1995), Morocco (Bouabid \& Martin, 2009), Republic of South Africa (Jeenah \& Pouris, 2008), Panama (Monge-Nájera \& Ho, 2015), Costa Rica (Monge-Nájera \& Ho, 2012), Taiwan (Chuang \& Ho, 2015), and Czech Republic (Fiala \& Ho, 2015).

The aim of this work was to analyze journal publications contributed by Camerounian researchers in the Science Citation Index Expanded (SCI-EXPANDED) of database from 1936 to 2015 . This study was divided into three parts: first, we conducted the overall scientific performance of Cameroon in SCI-EXPANDED. The second section dealt with publication activities, with major focus on favored journals and subject categories, in which Cameroonian major international collaborating partners and national inter-institutional collaborating players were identified. Finally, the most cited papers were examined as statements of discipline emphases and impact. 


\section{DATA SOURCES AND METHODS}

Science Citation Index Expanded (SCIEXPANDED) of Thomson Reuters Web of Science Core Collection was used to collect the bibliographic data. An advanced research was conducted for documents with the phrase "Cameroon" in the country field. Initially, 10 591 publications were identified and these documents were published between 1936 and 2015 (Data last updated: July 15 ${ }^{\text {th }}, 2016$ ).

Document information including names of authors, title, and year of publication, source journals publishing the articles, contact address, and each year's citation time for every publication were downloaded into Microsoft Excel 2013 software and additional coding was manually performed for origin country, institutions of the collaborators and impact factors of the publishing journals ( $\mathrm{Li} \& \mathrm{Ho}, 2008$ ). The reported impact factor $\left(I F_{2015}\right)$ of each journal was obtained from the 2015 JCR. The total number of times a document was cited from the Web of Science Core Collection since its publication to the end of 2015 was recorded as $T C_{2015}$ (Wang, Fu, \& Ho, 2011). Likewise, $C_{2015}$, the total number of citations of a paper in 2015 only (Ho, 2012) was employed to characterize Cameroon publications. In addition, the citations per total publications since publication $\left(C P P=T C_{2015} / T P\right)$, was also used (Chuang \& Ho, 2015).

Articles originating from England, Scotland, Northern Ireland, and Wales were reclassified as originating from the United Kingdom (UK).

Affiliations in Yugoslavia were checked to be in Slovenia.

Affiliations in UKSSR were checked to be in Ukraine.

Affiliations in Greenland were checked to be in Denmark.

Affiliations in Reunion were checked to be in France.

Affiliations in Czechoslovakia were checked to be in Czech Republic (Czech Republic).
Affiliations in Zaire were checked to be in Democratic Republic of the Congo (Dem. Rep. Congo).

Affiliations in People's Republic of the Congo (Congo Peopl Rep) and Republic of the Congo (Rep Congo) were checked to be in Republic of the Congo (Congo).

Affiliations in USSR were checked to be in Armenia or Russia.

Affiliations in Federal Republic of Germany (Fed Rep Ger) were checked to be in Germany.

\section{RESULTS AND DISCUSSION}

Document type and language of publication: A total of 10591 Cameroon publications with 12 documents types in the Science Citation Index Expanded from 1936 to 2015 were found. The majority of publications from Cameroon were formal articles: 8958 (85\% of 10591 publications), followed by meeting abstracts $842(8.0 \%)$, reviews $253(2.4 \%)$ and letters $232(2.2 \%)$ in the fourth position (Digital Appendix 1). Reviews had the highest citations per publication $(C P P)$ with 17 , followed by proceedings papers with 16 , and 11 for each of articles and notes respectively.

Altogether 8958 articles were extracted from the 10591 documents for further analyses. Ninety-one percent of all these journal articles were published in English (8141 articles), followed by French (804; $9.0 \%$ ), German (8 articles), Russian ( 2 articles), one in Italian and one in Chinese. One article was published in Soil \& Tillage Research which was a bilingual (Afrikaans and English) journal. Cameroon is a bilingual country and the French-speaking area represents almost $80 \%$ or eight regions against two English-speaking regions.

In Cameroon, there are eight universities with two in the Anglophone area: the University of Buea created in 1993 and the Bamenda created in 2010. Even though it is different for most Cameroonians to speak the English language at first, the study of English language only begins in secondary school in the Francophone regions. The fact that some journals 
agree to publish in French is therefore an advantage for them to avoid the English language. Another explanation is that Cameroon is the member of Francophonie, which involves countries whose official language is French and because of this, most documents are published in French. Today, 785 publications are made per year, up from 117 in 1993, showing a great improvement in Cameroon research. Analysis also showed that these articles have 54566 authors, indicating an average of 6.1 authors per publication, proving collaborative rather than independent research in Cameroon. A probable reason is that, in Cameroon, institutions do not offer financial incentives for the publication of smaller works such as meeting abstracts and reviews, so authors concentrate their efforts in the publication of articles which are used in the upgrading of researchers. These results obtained indicate that Cameroonian researchers actively take part in conferences, and the number of reviews gives an idea of their performance.

Publication year: A total of 8958 Cameroon articles were published in SCI-EXPANDED. Before the World War II (in 1936 to 1937); articles entitled "Cystic hygroma of the neck: Two cases in Bulu children" (Mc Crackin, 1936) and "Albinism: Albinism and unialbinism in twin African Negroes" (Mc Crackin, 1937) were published in American Journal of Diseases of Children by Robert H. McCrackin. After that, there were no further publications until 1972.

Recently, Ho (2013) proposed a relationship between classic articles and their citations per publication $\left(C P P=T C_{\text {year }} / T P\right)$ by years. It also applied to bibliometric of countries such as Taiwan (Chuang \& Ho, 2015), Czech and Slovakia (Fiala \& Ho, 2016), and Panama (Monge-Nájera \& Ho, 2015). Fig. 1 clearly

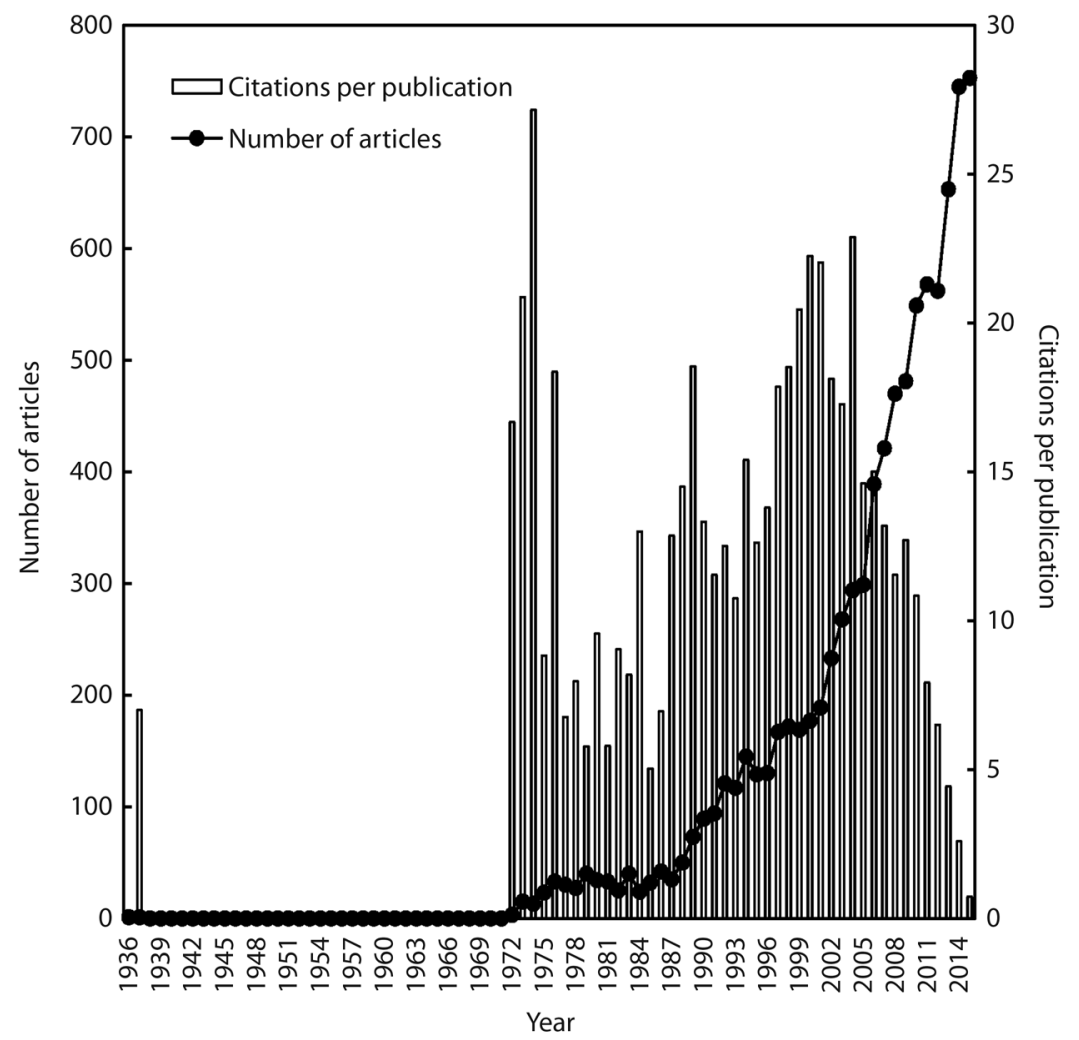

Fig. 1. Trend of the number of publications referring to Cameroon in the Science Citation Index Expanded, citation versions articles. 
illustrates that only one article was published in 1936 and 1937, respectively. No publications were made from 1938 to 1971, and no significant trend was observed from 1972 to 1987. The period from 1988 to 2015 observed a sharp increase in the number of publications from 50 to 735 articles. The CCP for 8958 Cameroon articles was 11 with a high CPP of 27 observed in 1974, and attributable to the article entitled "Studies on onchocerciasis in United Cameroon Republic. II. Comparison of onchocerciasis in rain-forest and Sudansavanna" (Anderson, Fuglsang, Hamilton, \& Marshall, 1974) with $T C_{2015}$ of 133.

International collaboration: Cameroon, not being endowed with real research centers and laboratories must collaborate with researchers from other countries (Table 1). This collaboration enables local researchers to have access to equipment. Of all Cameroon articles, 2331 (26\% of 8958 articles) were Cameroon independent articles while 6627 (74\%) were internationally collaborative articles with 174 countries. Table 1 lists the first top 10 countries having high collaboration with Cameroon in terms of research. The number of internationally collaborative articles, the rank of the total internationally collaborative articles together with the percentage of total Cameroonians articles and rank of first author articles and corresponding author articles are also presented in Table 1. This collaboration is dominated by France, ranked first in collaborative publications with 2549 (28\%) articles, and second in both first author and ranking of corresponding authors. USA follows far behind France with $1130(13 \%)$ articles, with a third position occupied by United Kingdom in both first authors and ranking of corresponding authors. The top four countries in this Table 1 have a total of $5285(58.2 \%)$ articles. These results showed that Cameroon is strongly dependent in terms of research. This high collaborative publication with France may be due to the fact that a number of lecturers in Cameroon studied in France, or had French fellowships, and they still maintain the relationship. Thus, due to the acute lack of equipment in Cameroonian universities, researchers are forced to seek foreign aid for their analyses. If Cameroon was independent in its research plan, and had adequate equipment, the research performance of Cameroon would have been better in the last 79 years.

Institutional comparisons: For institutional studies the universities in Cameroon were grouped, for example, Univ. Yaoundé 1, Univ. Yaoundé I, Univ. Yaoundé were grouped

TABLE 1

The top 10 most frequently collaborative countries with Cameroon in the Science Citation Index Expanded

\begin{tabular}{lcccc}
\multicolumn{1}{r}{ Country } & $C P$ & $C P R(\%)$ & $F P R(\%)$ & $R P R(\%)$ \\
France & 2549 & $1(28)$ & $2(13)$ & $2(13)$ \\
USA & 1130 & $2(13)$ & $3(6.1)$ & $3(6.0)$ \\
United Kingdom & 809 & $3(9.0)$ & $4(3.7)$ & $4(3.6)$ \\
Germany & 797 & $4(8.9)$ & $5(3.2)$ & $5(3.4)$ \\
Belgium & 504 & $5(5.6)$ & $6(2.4)$ & $6(2.4)$ \\
South Africa & 476 & $6(5.3)$ & $7(2.1)$ & $7(2.3)$ \\
Italy & 389 & $7(4.3)$ & $9(1.1)$ & $9(1.2)$ \\
Switzerland & 328 & $8(3.7)$ & $8(1.1)$ & $8(1.3)$ \\
Nigeria & 322 & $9(3.6)$ & $11(0.75)$ & $12(0.67)$ \\
Canada & 234 & $10(2.6)$ & $10(1.0)$ & $10(1.0)$ \\
\hline
\end{tabular}

$C P$ : internationally collaborative articles with Cameroon; $C P R(\%)$ : rank of internationally collaborative articles and percentage; FPR (\%): rank of article with first author and percentage; $R P R(\%)$ : rank of article with corresponding author and percentage. 
TABLE 2

Top 12 institutions for Cameroon articles in the Science Citation Index Expanded (TP $\geq 100)$

\begin{tabular}{lccccccc}
\multicolumn{1}{c}{ Institute } & $T P$ & $T P R(\%)$ & $\% S I(S I)$ & $\% I C(I C)$ & $\% N C(N C)$ & $\% F P(F P)$ & $\% R P(R P)$ \\
University of Yaoundé I & 4137 & $1(46)$ & $16(655)$ & $71(2936)$ & $13(546)$ & $47(1956)$ & $44(1811)$ \\
University of Dschang & 981 & $2(11)$ & $9.5(93)$ & $70(689)$ & $20(199)$ & $49(477)$ & $47(459)$ \\
University of Douala & 764 & $3(8.5)$ & $3.4(26)$ & $78(598)$ & $18(140)$ & $35(270)$ & $35(270)$ \\
University of Buea & 623 & $4(7)$ & $15(92)$ & $69(431)$ & $16(100)$ & $42(262)$ & $41(254)$ \\
University of Ngaoundere & 515 & $5(5.7)$ & $10(54)$ & $71(364)$ & $19(97)$ & $48(248)$ & $47(242)$ \\
Centre Pasteur Cameroon & 282 & $6(3.1)$ & $11(31)$ & $82(232)$ & $6.7(19)$ & $34(96)$ & $33(94)$ \\
Institute of Agricultural Research for Development & 273 & $7(3)$ & $8.8(24)$ & $81(221)$ & $10(28)$ & $38(104)$ & $35(95)$ \\
Organisation de Coordination pour la lutte contre les & 248 & $8(2.8)$ & $12(29)$ & $81(202)$ & $6.9(17)$ & $35(88)$ & $32(79)$ \\
Endemies en Afrique Centrale & 162 & $9(1.8)$ & $12(19)$ & $70(113)$ & $19(30)$ & $26(42)$ & $25(41)$ \\
Hopital Central de Yaoundé & 161 & $10(1.8)$ & $2.5(4)$ & $86(138)$ & $12(19)$ & $11(18)$ & $11(17)$ \\
Ministry of Public Health & 158 & $11(1.8)$ & $3.2(5)$ & $65(102)$ & $32(51)$ & $42(67)$ & $44(70)$ \\
University of Maroua & 116 & $12(1.3)$ & $12(14)$ & $79(92)$ & $8.6(10)$ & $35(41)$ & $35(41)$ \\
Institut de Recherche pour le Developpement & & & & & & &
\end{tabular}

$T P$ : total number of articles; TPR (\%): rank of total number of articles and percentage; \% SI (SI): percentage in $T P$ in an institute and institutional independent articles; \% IC (IC): percentage in TP in an institute and number of internationally collaborative articles; \% $N C(N C)$ : percentage in $T P$ in an institute and nationally collaborative articles; \% $F P(F P)$ : percentage in $T P$ in an institute and first author articles; \% $R P(R P)$ : percentage in $T P$ in an institute and corresponding author articles.

to be University of Yaoundé I. Of all articles by Cameroonians 1545 (17\% of 8958 articles) were single-institution articles, 7413 (83\%) were inter-institutionally collaborative articles, while $786(8.8 \%)$ were international collaborative articles. The most productive Cameroonian research institutions from 1936-2015 are presented in Table 2. A ratio of institutional independent (single institution) articles: internationally collaborative articles: national collaborative articles (S:I:N) might be used to describe institutions or authors' publication characteristics (Fu, Long, \& Ho, 2014). The S:I:N ratio of the University of Yaoundé $I$ is 16:71:13, and it is different from that the University of Dschang which is 9.5:70:20, while that of the University of Douala is 3.4:78:18. Of all the top 12 institutions of Cameroon articles in the Science Index Expanded (Table 2) show that more than $60 \%$ of the articles were international collaborative articles. The University of Maroua with S:I:N = 3.2:65:32 was less inclined to conduct institute and institutional independent research. This university also presented the smallest international collaboration. This is due to the fact the University of Maroua was just recently created in 2008 and most of its lecturers were already affiliated to those universities which existed since 1993. Table 2 demonstrates that the University of Maroua showed the highest national collaboration of $35 \%$. The University of Douala also presented poor institutional independent articles of $3.4 \%$. This ratio could show three important rates related to with college collaboration, which was more comprehensive and visual than just one traditional collaboration rate at a time for measurement and comparison (Fu et al., 2014). However, the best performance comes from the university of Yaoundé I with 4137 (46\%) of Cameroonian publications, followed far behind by the University of Dschang with 981 (11\%), while the University of Douala occupies the third position with 764 $(8.5 \%)$ publications. It is worth noting that the University of Yaoundé I existed more than 20 years with different names, before the creation of the other universities and constitute more than $50 \%$ of lecturers in Cameroon. This ranking (first five) is dominated by state universities in Cameroon, which iterates teacher quality of Cameroonian universities known 


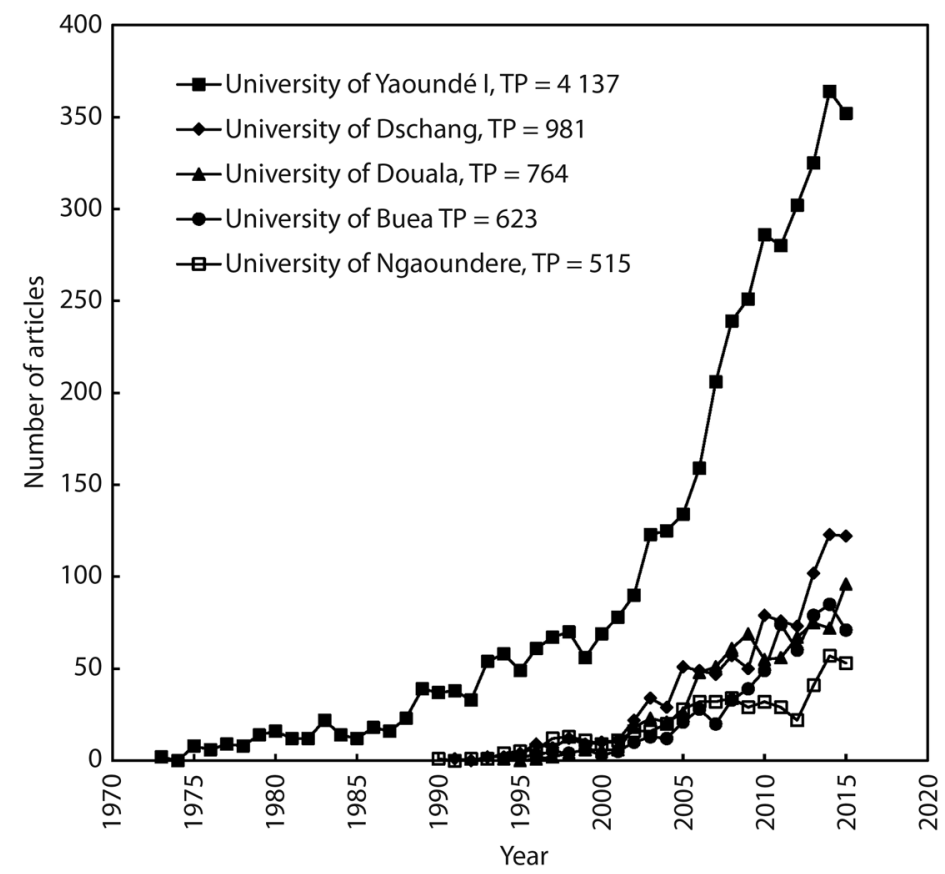

Fig. 2. The top five most productive institutions in Cameroon with more than 500 publications in the Science Citation Index Expanded.

under the name of teacher-researchers. In addition to the overall productivity of institutions, it is interesting to identify their independent paper $(I C)$, collaborative papers $(C I)$, first author paper $(F P)$, corresponding author papers $(R P)$ and institutional independent articles (II). The absolute numbers along with the corresponding total productivity of each institution can be seen in Table 2. Fig. 2 shows the institutional yearly productivity for the five Cameroonian universities. From the results obtained, it is clear that the first publications of the University of Yaoundé I date back to 1973, followed by the University of Ngaoundéré before the growth observed from 2005. In addition, the University of Douala observed an increase in the number of publications from late 2014 to early 2015, while the other universities observed a decrease. The figure also shows that the universities of Douala, Ngaoundéré, and Dschang had publications before their creation in 1993. This is so because the sites where the universities are located had schools or training centers which were later transformed to universities.

\section{Web of Science categories and journals:} Based on the classification of subject categories, the article output data was distributed into 169 SCI-EXPANDED subject categories. The top fourteen productive subject categories and the number of the journals of each category are shown in Fig. 3. (Note: Fig. 3 and Fig. 4 are in Digital Appendix 2) Tropical medicine (8.5\%) is at the top of Cameroonian publications, closely followed by plant sciences $(8.4 \%)$, then environmental and occupational public health $(7.5 \%)$, and infectious diseases $(7.4 \%)$. This ranking is dominated by activities related to research on medicinal plants.

Concerning the most cited 20 Cameroonian authors (Table 3 , note: Table 3 and table 4 are in DIGITAL APPENDIX 3), authors from the field of physics occupied the first and third positions, while authors from biochemistry occupied the fourth position. The second, fifth, 
sixth, seventh and eight positions are occupied by chemistry authors, specifically authors in the domain of natural substances (plants) in organic chemistry. It was also noted that most of this plant extracts were analyzed for their pharmacological properties. Table 4 shows that the most cited Cameroonian article was a mathematics article published by Nguetseng in 1989, whose name did not appear in Table 3. This confirms the fact that research in Cameroon is mainly dependent on cooperation abroad. His article was seconded by that of Gardon et al., a research of Centre Pasteur Cameroon published in 1997, and the remaining articles were beyond the hundredth row even if the third is still occupied by a mathematics article with author Bowong (2004).

A strong conclusion can be drawn from Figure 4 that, neither the first author nor the corresponding author of the most cited article are Cameroonian. This is either due to the fact that the articles were published in research groups in which Cameroonians are members or they are articles arising from doctoral and postdoctoral fellowship programs. The Figure 4 demonstrates a good representation of independent articles of $6 \%, 7 \%$ of those whose first authors are Cameroonian, $6.9 \%$ of those having Cameroonian corresponding authors and $6.9 \%$ of those with Cameroonian being first and corresponding authors. Nevertheless, it can be concluded that Cameroonian researchers are mostly integrated into research groups abroad. The top institutional rankings are dominated by state institutions. This indicates that although there is no adequate research equipment, universities are the best research centers in the country.

This work presents a bibliometric analysis of articles published by at least one author from Cameroon during the period 1936-2015 and indexed in the Thomson Reuters SCIEXPANDED database based on the production and citations, overall performance, subject categories, international and inter-institutional collaboration, and most cited paper. Cameroon has developed in scientific performance in 14 fields. Biochemistry and molecular biology and Pharmacology and Pharmacy were the two most productive fields to SCI papers. In terms of international collaboration, more than $90 \%$ of all articles by Cameroonians papers were by international collaborations. Moreover, France and USA dominated the ranking of the more collaborative countries with Cameroon. For national/ inter-institutional collaboration, the University of Yaoundé 1 was the most productive institution and the other most productive universities were the University of Dschang and University of Douala. Furthermore, international collaboration enhanced the most citation-rate of papers in most fields.

\section{RESUMEN}

Publicaciones de Camerún en el Science Citation Index Expanded: análisis bibliométrico. Camerún es uno de los seis países de África Central con más de 20 millones de habitantes. Para caracterizar el desempeño de la investigación de Camerún, las publicaciones de los Camerúnes en el Science Citation Index Expanded durante el período de 1936-2015, indexadas en la base de datos Thomson Reuters SCI-EXPANDED, fueron estudiadas en este trabajo. Todos los documentos de ese período con Camerún en el campo de dirección fueron incluidos en el estudio. Se analizaron el tipo de documento, el idioma, la tendencia y las colaboraciones, así como el resultado de diferentes categorías de temas. También se analizaron las interpretaciones de los países, instituciones y autores, incluyendo el total, único, colaborativo, primer autor, y publicaciones de autor correspondientes. Los artículos fueron analizados por la producción científica y los resultados de investigación de individuos, instituciones y países colaborativos con Camerún. Los análisis incluyeron 8457 artículos (85\% de 10591 publicaciones de Camerún). Estos análisis bibliométricos de las publicaciones camerunesas aportaron ideas interesantes sobre autores, instituciones y modelos de colaboración. Los resultados mostraron que la investigación en Camerún era altamente dependiente de colaboraciones extranjeras, y la colaboración internacional fue responsable del creciente número de publicaciones a lo largo de los años. Se encontró que los artículos con autores primarios o autores correspondientes de fuera de Camerún obtuvieron más citas que los otros y que los artículos sin ninguna colaboración internacional tenían citas más bajas. El número de artículos indexados por SCI-EXPANDED ha mostrado un aumento en términos de artículos cameruneses que es considerablemente mayor que el aumento en el número de todos los artículos en SCI-EXPANDED. Los artículos eran más frecuentes que otros tipos de publicación y en su mayor parte en inglés. La Universidad de Yaundé I ocupó el primer lugar en artículos de colaboración interinstitucional, 
el rango de los artículos de colaboración interinstitucional y el rango de los artículos del primer autor y los artículos de autores correspondientes. La Universidad de Yaundé I también estuvo en una posición de liderazgo absoluta desde 1970 hasta 2015, seguida muy de lejos por las otras instituciones. Las categorías de medicina tropical, ciencias vegetales, salud pública ambiental y ocupacional, y enfermedades infecciosas, representaron el mayor número de artículos publicados. Aunque la física y la química dominaron el ranking de los 20 mejores autores cameruneses, un artículo independiente de matemáticas fue el más citado, con 60 citas en 2015 a un autor camerunés. Los tres principales investigadores productivos fueron: T. C. Kofane, B. T. Ngadjui, P. Woafo, todos de la Universidad de Yaundé I. Francia y Estados Unidos dominaron el ranking de países con una fuerte colaboración científica con Camerún.

Palabras clave: África, Web of Science, análisis bibliométrico, Camerún, Science Citation Index Expanded.

\section{REFERENCES}

Anderson, J., Fuglsang, H., Hamilton, P. J., \& Marshall, T. F. (1974). Studies on onchocerciasis in United Cameroon Republic. II. Comparison of onchocerciasis in rain-forest and Sudan-savanna. Transactions of the Royal Society of Tropical Medicine and Hygiene, 68(3), 209-222.

Biya, P. (1992). Décret N 92/74 du 13 Avril 1992 portant transformation des centres universités en universités. Cameroon Tribune, p. 2.

Biya, P. (1993). Décret N93/026 du 19 Janvier 1993 portant création des universités. Cameroon Tribune, p. 2.

Bouabid, H., \& Martin, B. R. (2009). Evaluation of Moroccan research using a bibliometric-based approach: Investigation of the validity of the h-Index. Scientometrics, 78(2), 203-217.

Chuang, K. Y., \& Ho, Y. S. (2015). An evaluation based on highly cited publications in Taiwan. Current Science, 108(5), 933-941.

De Haan, J. (1997). Authorship patterns in Dutch sociology. Scientometrics, 39, 197-208.

Fiala, D., \& Ho, Y. S. (2015). Twenty years of Czech science: A bibliometric analysis. Malaysian Journal of Library \& Information Science, 20(2), 85-102.

Fiala, D., \& Ho, Y. S. (2016). Comparison of Czech and Slovak independent research in the $21^{\text {st }}$ century. Current Science, 110(8), 1524-1531.

Fu, H. Z., \& Ho, Y. S. (2013). Independent research of China in Science Citation Index Expanded during 1980-2011. Journal of Informetrics, 7(1), 210-222.
Fu, H. Z., Long X., \& Ho, Y. S. (2014). China's research in chemical engineering journals in Science Citation Index Expanded: a bibliometric analysis. Scientometrics, 98, 119-136.

Glänzel, W. (1996). A bibliometric approach to social sciences. National research performances in 6 selected social science areas, 1990-1992. Scientometrics, 35(3), 291-307.

Glänzel, W. (2000). Science in Scandinavia: A bibliometric approach. Scientometrics, 48(2), 121-150.

Guan, J., \& Gao, X. (2008). Comparison and evaluation of Chinese research performance in the field of bioinformatics. Scientometrics, 75(2), 357-379.

Hannerz, M. (2010). Top-cited articles 2001-2009: Scandinavian. Journal of Forest Research, 25, 1-2.

Ho, Y. S. (2012). Top-cited articles in chemical engineering in Science Citation Index Expanded: A bibliometric analysis. Chinese Journal of Chemical Engineering, 20(3), 478-488.

Ho, Y. S. (2013). The top-cited research works in the Science Citation Index Expanded. Scientometrics, 94(3), 1297-1312.

Ivanović, D., \& Ho, Y. S. (2014). Independent publications from Serbia in the Science Citation Index Expanded: A bibliometric analysis. Scientometrics, 101(1), 603-622.

Ivanović, D., Fu, H. Z., \& Ho, Y. S. (2015). Publications from Serbia in the Science Citation Index Expanded: A bibliometric analysis. Scientometrics, 105(1), 145-160.

Jeenah, M., \& Pouris, A. (2008). South African research in the context of Africa and globally. South African Journal of Science, 104, 351-354.

Li, Z., \& Ho, Y. S. (2008). Use of citation per publication as an indicator to evaluate contingent valuation research. Scientometrics, 75(1), 97-110.

Lucio-Arias, D., \& Leydesdorff, L. (2009). An indicator of research from activity: measuring intellectual organisation as uncertainty reduction in documents sets. Journals of American Society for Information Science and Technology, 60(12), 2488-2498.

Markusova, V. A., Jansz, M., Libkind, A. N., Libkind, I., \& Varshavsky, A. (2009). Trends in Russian research output in post-Soviet era. Scientometrics, 79(2), 249-260.

McCrackin, R. H. (1936). Cystic hygroma of the neck: Two cases in Bulu children. American Journal of Diseases of Children, 51(2), 349-352. 
McCrackin, R. H. (1937). Albinism: Albinism and unialbinism in twin African Negroes. American Journal of Diseases of Children, 54(4), 786-794.

Moed, H. F., de Bruin, R. E., \& Van Leeuwen, Th. N. (1995). New bibliometric tools for the assessment of national research performance: Database description, overview of indicators and first applications. Scientometrics, 33(3), 381-422.

Monge-Nájera, J., \& Ho, Y. S. (2012). Costa Rica publications in the Science Citation Index Expanded: A bibliometric analysis for 1981-2010. Revista de Biología Tropical, 60(4), 1649-1661.

Monge-Nájera, J., \& Ho, Y. S. (2015). Bibliometry of Panama publications in the Science Citation Index Expanded: Publication type, language, fields, authors and institutions. Revista de Biología Tropical, 63(4), 1255-1266.

Moravcsik, M. J. (1985). Applied scientometrics: An assessment methodology for developing countries. Scientometrics, 7(3-6), 165-176.

National Institute of Statistics (INS). (2010). Third general population and housing census. p. 59.

Ndjodo, F. M., \& Onana, A. C. (2012). Rapport de recherché sur les reformes de gouvernance dans l'enseignement supérieur Camerounais. IIEP/Prg. MM/SEM331, UNESCO 2012, p. 65.
Ponce, F. A., \& Lozana, A. M. (2010). Highly cited works in neurosurgery. Part I: the 100 top-cited papers in neurosurgical journals: A review. Journal of Neurosurgery, 112, 223-232.

Pouris, A. (1989). Strengths and weaknesses of the South African Science. South African Journal of Science, $85,623-626$.

Schubert, A., Glänzel, W., \& Braun, T. (1989). Scientometric datafiles: A comprehensive set of indicators on 2649 journals and 96 countries in all major science fields and subfields 1981-1985. Scientometrics, 16(16), 3-478.

Shadgan, B., Roig, M., Hajghanbari, B., \& Reid, W. D. (2010). Top cited articles in rehabilitation. Archives of Physical Medecine and Rehabilitation, 91, 806-815.

Wang, M. H., Fu, H. Z., \& Ho, Y. S. (2011). Comparison of universities' scientific performance using bibliometric indicators. Malaysian Journal of Library and Information Science, 16(2), 1-19.

Wang, M. H., Yu, T. C., \& Ho, Y. S. (2010). A bibliometric analysis of the performance of Water Research. Scientometrics, 84(3), 813-820.

Yamazaki, S. (1994). Research activities in life sciences in Japan. Scientometrics, 29(2), 181-190.

\section{See Digital Appendix at: / Ver Apéndice digital en: revistas.ucr.ac.cr}

